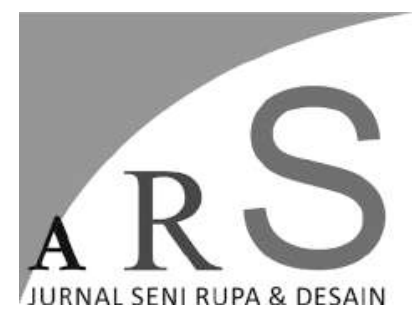

Volume 21 Nomor 2 - Agustus 2018

\section{INSTAGRAM SELFIE DI PAMERAN ARTJOG}

\author{
Nadiyah Tunnikmah \\ Program Studi Seni Rupa Murni, Minat Utama Seni Grafis, Jurusan \\ Seni Murni, Fakultas Seni Rupa, Institut Seni Indonesia Yogyakarta \\ E-mail: nadiyahtunnikmah@gmail.com
}

\begin{abstract}
ABSTRAK
Selfie instagram di pameran artjog adalah sebuah riset yang dilakukan dengan tujuan untuk mengidentifikasi bagaimana selfi dilakukan di antara karya seni dalam sebuah pameran seni menggunakan media sosial maupun untuk menentukan bagaimana pengaruh media sosial terhadap pengunjung pameran. Objek penelitian dibatasi pada selfi-selfi dengan karya seni dengan media sosial instagram dan dilakukan pada 2016. Karya pamer yg dipilih dalam kajian ini adalah yang dipamerkan di artjog. Pengumpulan data instagram dilakukan dengan kategori-kategori pencarian meta data berdasarkan tanda tagar. Seleksi selfi di pameran artjog dilakukan setelah melihat selfi di pameran yang merajalela juga melihat jumlah unggahan dengan tagar artjog mencapai 25.883 dan didominasi oleh selfi. Kebanyakan aksi selfi dengan karya seni dan ditampilkan di ruang-ruang publik dilakukan tanpa menyebutkan identitas karya tersebut dan menambahkan sebuah 'keterangan' baru pada karya tersebut tanpa ijin dari penciptanya.
\end{abstract}

Kata kunci: selfie, ArtJog, sosial media

\begin{abstract}
Instagram Selfie in ArtJog exhibition is a research conducted with purpose to identify how selfie done with artwork in an art exhibition using social media as well as to determine the effect of social media on the art exhibitions visitor. The object of this study is limited to selfies with artwork that uses social media instagram and conducted in 2016. The exhibits were selected in this study will be limited in ArtJog exhibition. Instagram data collection is done by using meta data search categories based on hashtag. The selection of selfies at the artjog exhibition was done after seeing the rampant selfie at the exhibition also saw the number of uploads with hastag ArtJjog reaching 25,883 and dominated by selfies. Most Selfe actions with artwork and publish on public pages done without mentioning the identity of the artwork and give a new "caption" on the artwork without the permission of the artist.
\end{abstract}

Keyword: selfie, ArtJog, Social Media 


\section{Pendahuluan}

Media sosial merupakan media untuk bertukar informasi atau menyebarkan informasi. Istilah media sosial saat ini identik dengan media sosial yang berbasis internet. Jumlah media sosial di Internet dalam sepuluh tahun terkhir berkembang menjadi lebih interaktif dan disesuaikan dengan alat komunikasi yang banyak digunakan oleh para pengguna internet. Alat komunikasi yang awalnya berupa komputer dan telepon seluler berkembang dengan adanya tablet dan kamera yang ada hampir disemua alat tersebut.

Kamera yang ada hampir disemua telepon seluler membuat penggunaan kamera menjadi sangat umum dan fungsinya juga meluas. Salah satunya adalah penggunaan kamera pada telepon seluler untuk media sosial. Penggunaan kamera dan media sosial ini memunculkan kebiasaan berfoto setiap saat setiap waktu. Kebiasaaan tersebut memunculkan istilah selfie yang berasal dari kata selfish yang berarti egois, mementingkan diri sendiri. Selfie sangat sering digunakan hingga akhirnya menjadi kata yang resmi pada kamus pada tahun 2013.

A Photograph that one has taken ofe oneself, typically one taken with a smartphone or webcam and shared via social media (http:l/www. oxforddictionaries.com). Selfie paling banyak digunakan pada media sosial instagram yang memang sesuai dengan ketentuan menggunakan media sosial tersebut yaitu hanya menggunakan foto sebagai sarana unggah. Semakin maraknya penggunaan instagram membuat semakin lazimnya aktivitas selfie. Hampir semua kegiatan dijadikan selfie, mulai dari makan, berbelanja, masak, menonton konser dan sebagainya. Kegiatan mengunjungi tempat menjadi ajang selfie yang digemari, salah satunya kegiatan berkunjung ke pameran seni rupa.

\section{Rumusan Masalah}

Apakah selfie dengan karya seni pada pameran seni ArtJog merupakan apresiasi?

\section{Tinjauan Pustaka}

Penelitian atau tulisan mengenai selfie sendiri lebih banyak dilakukan berhubungan dengan perilaku yang berkaitan dengan psikologi. Ada dua tulisan mengenai selfie yang dimunculkan di Jurnal of Urban Society's Arts ada dua dibuat oleh Kusrini. Pada tahun 2013 Kusrini menulis artikel dengan judul " Selfie sebagai Perangkat Citra Diri Masyarakat Urban" dan pada tahun 2015 dengan judul "Potret Diri Digital dalam Seni dan Budaya Visual". Keduanya membahas tentang selfie lebih kepada kajian selfie sebagai potret diri tidak secara spesifik selfie yang berkaitan dengan aktivitas lain.Tulisan atau artikel di internet mengenai perilaku pengunjung pameran yang melakukan selfielebih bayak merujuk pameran yang ada di luar negri. Oleh sebab itu penelitian dengan judul "Selfie Dengan Karya Seni di Pameran Seni Rupa Menggunakan Media Sosial“ layak dilakukan.

\section{Landasan Teori}

Penelitian ini merupakan penelitian kualitatif yang berusaha untuk medefinisikan kegiatan selfie menggunakan media sosial Instagram yang semakin marak dilakukan pada pameran seni rupa. Dalam seni rupa kehadiran pengunjung atau masyarakat dalam pameran selama ini dianggap sebagai salah satu bentuk apresiasi terhadap karya seni yang ada dalam pameran. Apresiasi dalam seni berkaitan erat dengan estetika dan filsafat seni atau wawasan yang berkaitan dengan seni.Apresiasi terhadap seni rupa yang paling utama dilakukan adalah dengan melihat karya langsung melaui datang ke pameran seni rupa. Kegiatan melihat langsung karya seni rupa dilakukan dalam semua priode seni yang ada. Pameran seni rupa biasa diselenggarakan terbuka untuk umum, bisa didatangi oleh siapa saja. Namun pengunjung pameran seni rupa selama ini memang berjumlah terbatas, khusus didatangi oleh kalangan tertentu yang memang peminat seni. Para peminat seni pada umumnya sudah mempunyai pengetahuan tentang karya seni khususnya yang diminati.

\section{"The understanding and appreciation of art are enhanced by familiarity with three areas of art: the language of art (visual elements, principles of design, and style), the nature of the mediums used in art, and the history of art" (Lois, 2013:18)}

Apresiasi tentang seni diawali dengan 
mengevaluasi karya seni. Evaluasi mengenai seni meliputi deskripsi dan diskusi tentang seni. Ada beberapa bagian untuk berkaitan dengan mengevaluasi karya seni. Pertama, menurut pemahaman umum mengenai seni, untuk menyebut suatu objek sebagai karya seni berarti sudah menganggap benda tersebut dinilai dengan positif. Apa yang disebut sebagai karya seni idealnya sesuai dengan kriteria tentang nilai artistik yang ada, sehingga apapun karya seni tersebut tetap lebih baik dari objek yang pokok isinya bertujuan untuk disebut karya Seni tapi tidak memenuhi kriteria nilai artistik yang ada. Kedua, karya seni dibuat untuk diapresiasi dan kita melihat dengan tujuan mengapresiasi. Apresiasi adalah memahami, menikmati dan mengenali nilai artistik yang ada dalam karya seni. (Steven \& Cahn, 2004:93)

Apresiasi terhadap seni rupa yang paling sering dilakukan adalah melihat karya langsung dengan cara datang ke pameran seni rupa. Bentuk apresiasi dengan melihat langsung karya seni rupa dilakukan dalam semua priode seni yang ada. Pameran seni rupa biasa diselenggarakan terbuka untuk umum, bisa didatangi oleh siapa saja. Namun pengunjung pameran seni rupa selama ini memang berjumlah terbatas, khusus didatangi oleh kalangan tertentu yang memang peminat seni. Para peminat seni pada umumnya sudah mempunyai wawasan tentang karya seni khususnya yang diminati.

Tindakan atau perilaku manusia dilakukan bisa secara spontan, tidak sadar atau tanpa analisa diri. Desmond Morris dalam bukunya " Man Watching” menjelaskan tentang berbagai jenis perilaku manusia. Ada 4 hal yang membuat manusia mempunyai berbagai jenis perilaku tersebut yaitu melalui penemuan pribadi, penyerapan sosial, warisan genetis dan pelatihan yang disengaja (Morris, 1977:21)

Selfie merupakan perilaku yang timbul dari penemuan pribadi dan penyerapan sosial. Setiap manusia mempunyai bentuk selfie yang berbeda walau tidak dipungkiri penyerapan sosial membuat antara selfie satu dengan yang lain terlihat mempunyai kesamaan.

Kamera sebagai alat utama dalam perilaku selfie mempunyai kemampuan mereproduksi atau menduplikat. Penemuan kamera nyata pertama pada tahun 1826 mempengaruhi banyak aspek kehidupan salah satunya kesenian. Walter Benjamin menulis dalam essaynya yang berjudul The Work of Art in the Age of Mechanical Reproduction tentang kemungkinan dampak penemuan kamera terhadap karya seni. Dampak yang diperkirakan juga meliputi perilaku dan persepsi manusia terhadap kamera dan karya seni.

Pada abad ke 20, efek sosial dari munculnya kamerayang mempengaruhi kebudayaan dianalisa oleh Walter Benjamin. Dalam tulisannya pada pertengahan tahun 1930an mengenai reproduksi mekanik, Benjamin menjelaskan tentang aura dalam proses berkesenian yang muncul pada karya seni terpengaruh atau hilang dengan kemunculan teknologi reproduksi mekanik salah satunya kamera. Saat kamera menangkap gambar atau peristiwa unik pada tempat dan waktu tertentu gangguan privasi berlangsung. Jika yang difoto adalah karya seni, keunikannya akan hancur. Kehilangan keotentikan atau aura terjadi saat karya seni dilihat dari berbagai konteks, misal saat lukisan dijadikan perangko, kartu pos atau ditampilkan pada baliho iklan maka akan timbul asosiasi lain yang berbeda. (Benjamin, 2008: 19-40)

\section{Media Sosial}

Budaya visual saat ini merupakan hasil dari pengungkapan subjektivitas yang berlangsung pada abad 18, yang dikenal dengan sebutan era pencerahan. Fokus manusia mulai berubah pada diri sendiri dan memunculkan kekuatan akan sebuah kebutuhan tetap dari menjadi seorang individu. Manusia melihat tubuh mereka, perilaku, serta tempat di alam semesta. Gagasan tentang martabat manusia sebagai individu tersebar luas. Manusia tidak lagi dilihat semata sebagai alat untuk memuaskan tujuan politik atau penguasaan tertentu, melainkan sebagai sesuatu yang bernilai darn berharga pada dirinya sendiri. Setiap orang unik dan bebas, serta tidak perlu selalu tunduk pada otoritas di luar dirinya.

Pada abad berikutnya perkembangan teknologi pada tubuh manusia dan caranya digunakan berubah secara radikal. Bahkan kemampuan tubuh manusia pada beberapa dekade terakhir telah meningkat dengan ditemukannya 
komputer dan smart phone. Semua terkoneksi dengan internet dan dilengkapi dalam alat penghibur lainnya seperti kamera dan beberapa aplikasi lainnya. Media pada teknologi terbaru (dalam kurun waktu 10 tahun) mengalami percepatan yang mempengaruhi berbagai aspek kehidupan.

Istilah "user-generated content" sering digunakan untuk merujuk kepada banyak orang dengan kegiatan yang sama sebagaimana dimaksud oleh "media sosial". Istilah "user"sendiri menyiratkan hubungan dengan sebuah komputer dan peran sebagai seseorang yang mengontrol beberapa sumber lain dari konten, seperti profesional diproduksi berita, seolah-olah mereka hanya semacam saluran operator pemrosesan pada komputer pusat. Media sosial adalah tentang orang mempengaruhi lain orang lain dalam situasi sosial melalui teknologi. Tidak jarang semacam komputer ada untuk membantu,hasilnya situasi satu orang mempengaruhi sekelompok orang lain, tapi media sosial adalah tentang apa yang orang lakukan untuk mempengaruhi orang lain setidaknya sama sebanyak teknologi yang mereka gunakan untuk melakukannya. (Blossom, 2009: 30)

Demistifikasi media sosial hari ini sebagai alat mempercepat akses, pengaruh dan pengguna. Media sosial telah menjadi bagian tak terelakkan dari kehidupan sehari-hari, suka atau tidak suka. Media sosial adan dan akan selalu ada. Istilah Media Sosial tidak memerlukan penjelasan, karena setiap orang telah mendengar dan tahu itu sekarang. Secara sederhana media sosial dikenal sebagai media yang memungkinkan seseorang untuk menjadi sosial, atau bisa online kehidupan sosial dengan berbagi konten, berita, foto dan lain lain dengan orang lain.

Pada dasarnya, orang tertarik dalam jaringan untuk berhubungan dengan teman-teman, berbagi konten, mengirim pesan, berkolaborasi dengan satu sama lain secara waktu terkini, mengumpulkan berita/informasi/umpan balik atau hanya mengunggah/ download file media (film/musik/foto) di Internet. Media dalam bentuk situs yang memungkinkan mereka untuk melakukan hal-hal ini dengan mudah menjadi situs media sosial. Hari ini, media sosial telah secara substansial mengubah cara organisasi, komunitas, dan individu berkomunikasi satu sama lain.Media sosial telah membuka jalan baru bagi orang untuk terlibat dengan satu sama lain dengan konten yang tersedia di Internet. Interaksi sosial sebelum internet mempunya berbagai keterbatasan, sekarang secara "online" banyak batasan dihilangkan, membuka sebuah dunia dengan banyak kemungkinan baru.

Orang menggunakan media sosial untuk tetap berhubungan dengan berbagai hobi mereka, seperti musik, film, olahraga dan lain-lain. Media sosial memungkinkan seseorang untuk menemukan orang lain dengan minat yang sama. Orang-orang dapat menggunakan media ini untuk mengeksplorasi kreativitas. Setiap media sosial mempunya karakter berbeda dan sangat mudah untuk menjangkau khalayak yang besar. Seseorang dapat menggunakan situs berbagi foto untuk mengunggah dan menyimpan foto pribadi mereka dengan semua privasi mereka secara utuh atau selektif berbagi dengan orang lain. Banyak situs berbagi foto menggabungkan alat mengedit foto yang dapat digunakan untuk mengedit, meningkatkan foto untuk penggunaan pribadi.

\section{Instagram}

Media sosial yang muncul mempunyai bentuk dan fungsi yang berbeda. Twitter mengkhususkan diri pada teks dengan batasan 140 karakter. Walaupun Twitter bisa digunakan untuk menampilkan foto tapi itu bukan bentuk utama. Facebook adalah fenomena sosial yang bisa menggunakan teks dan foto tetapi menjadi favorit lebih kepada kemampuan terkoneksi dengan orang banyak terutama teman-teman lama.Instagram menjadi berbeda karena hanya bisa digunakan dengan mengunggah foto atau video.Teks hanya bagian kecil dan tidak diutamakan. Kemampuan menampilkan foto pada instagram membuat foto yang diunggah menjadi sekedar dari dokumentasi. Tampilan foto tidak hanya pada visual tapi juga tema yang berhubungan dengan orang, benda atau tempat.

Instagram adalah aplikasi pada telepon pintar untuk berbagi foto, video secara online dan layanan jejaring sosial yang memungkinkan penggunanya untuk mengambil gambar dan video, dan berbagi secara umum atau pribadi. Instagram juga bisa terkoneksi melalui berbagai 
platform jejaring sosial lainnya, seperti Facebook, Twitter, Tumblr, dan Flickr. Awalnya, fitur khasInstagram adalah foto hanya bisa berbentuk persegi mirip dengan Kodak Instamatic dan Polaroid SX-70 yaitu gambar, kontras dengan rasio aspek 4: 3. Pada bulan Agustus 2015, versi 7.5 dirilis, yang memungkinkan pengguna untuk meng-upload media ditangkap di setiap aspek rasio. Pengguna juga dapat menerapkan filter digital untuk gambar mereka.

Instagram diciptakan oleh Kevin Systrom dan Mike Krieger, dan diluncurkan pada bulan Oktober 2010 sebagai aplikasi mobile gratis. Layanan media sosial yang cepat mendapatkan popularitas, dengan lebih dari 100 juta pengguna aktif per April 2012 dan lebih dari 300 juta pada Desember 2014. Instagram didistribusikan melalui Apple App Store dan Google Play. Dukungan untuk aplikasi yang tersedia untuk iPhone, iPad, iPod Touch, dan Android.

Instagram adalah cara yang menyenangkan dan unik untuk berbagi hidup Anda dengan teman-teman melalui serangkaian gambar. Jepret foto dengan ponsel Anda, lalu pilih filter untuk mengubah gambar ke dalam memori untuk menjaga selamanya. Kami sedang membangun Instagram untuk memungkinkan Anda untuk mengalami saat-saat dalam kehidupan teman Anda 'melalui gambar saat mereka terjadi. Kami membayangkan dunia lebih terhubung melalui foto (www.instagram.com).

Instagram telah mengadopsi model pengikut yang berarti jika akun instagram disiapkan dalam bentuk publik, siapa pun dapat berlangganan untuk mengikuti foto Anda. Instagram juga memiliki pilihan pribadi khusus. Dalam mode ini, pengguna dapat memastikan harus menyetujui semua permintaan mengikuti sebelum disetujui mengikuti akun yang diaturpribadi. Semua foto diatur secara yang publik berarti bisa terlihat siapa saja yang menggunakan Instagram atau di situs web instagram.com.

Pada bulan Januari 2011, Instagram menambahkan hashtag untuk membantu pengguna menemukan baik foto, dan satu sama lain. Instagram mendorong pengguna untuk membuat tagar spesifik dan relevan, bukan penandaan kata generik seperti "foto", untuk membuat foto menonjol dan menarik pengguna
Instagram. Adapun syarat dasar penggunaan yang pengguna Instagram harus ikuti seperti beberapa media sosial lainnya, termasuk persyaratan usia 13 tahun atau lebih tua, pembatasan terhadap postingan kekerasan, telanjang, sebagian telanjang, atau bernada seksual.Banyak selebriti memiliki profil di Instagram, berbagi foto dan video dari kehidupan pribadi dan profesional mereka dengan fans.

\section{Selfie}

"Mau selfie dulu" menjadi kalimat yang sering diucapkan dan didengar. Selfie muncul seiring dengan munculnya media sosial. Selfie mulai muncul pertamakali melalui My Space pic di media sosial My Space pada tahun 2005. Kemunculan media sosial lain seperti facebook dan twitter juga mulai menguatkan selfie.

Tahun 2010 perusahaan Apple merilis I Phone 4 yang mempunyai kamera menghadap kedepan yang membuatselfie semakin mudah dilakukan.Perkembangan tersebut diikuti oleh semua perusahaan pembuat ponsel yang membuat penggunaan ponsel pintar dengan kamera depan dan belakang menjadi hal biasa. Saat hampir semua jenis telepon genggam terintegrasi dengan kamera, kesempatan berupa alat untuk mengabadikan diri sendiri membuat aktivitas selfie menjadi sering dilakukan.Tahun 2011 media sosial Instagram merilis penggunaan hastag yang membuat interaksi menjadi lebih menarik. Penggunaan hastag juga semakin membuat Instagram sebagai media sosial yang berbasis penggunaan foto semakin kuat dan banyak digunakan.

Selfie mungkin berakar dalam potret diri, dimana secara alami adalah sebuah hal biasa dalam dunia seni rupa, seperti yang terlihat pada potret diri Rembrandt dan Van Gogh. Revolusi visual yang merupakan dampak dari teknologi saat ini menyingkirkan seniman dalam konteks ini menyamakan dengan setiap pengguna kamera. Sayangnya bahkan istilah potret diri menjadi sebuah anakronisme.Potret diri yang dibuat untuk dibaca sebagai karya seni, ditampilkan di museum atau galeri. Pengunjung diberi izin untuk melihat mereka sebagai teks, berfungsi secara independen sebagai ekspresi si seniman. 
Selfie menjadi bagian dari praktik fotografi dan dibawakemuseum dangalerioleh pengunjung. Hal ini sukar untuk melihat narsis dengan cara yang sama sebagai seni, mengabaikan konteks interaksi sosial dan maksud dari pembuat selfie. Selfiesaat ini menjadi bagian dari percakapan, serangkaian interaksi kontekstual.Selfie dengan demikian kurang lebih seperti dokumen dari pidato seperti potongan bahasa yang diwujudkan secara visual. Selfie mendorong diskusi aktif saat ditampilkan dimedia sosial,mewakili citra diri pengguna, yang digunakan dalam cara yang mirip dengan propaganda.

Manusia menggunakan potret sebagai cara untuk menggambarkan gambar diri untuk membangkitkan respon. Salah satu alasan selfie menjadi intens dilakukan adalah bagaimana selfiedijadikan cara untuk membuat pengguna merasa baik tentang diri mereka sendiri dari komentar positif atau suka. Tujuan dari selfie di media sosial adalah untuk mendapatkan tanggapan. Hal ini adalah sesuatu yang sudah dilakukan manusia sejak lama. Manusia mempunyai kecenderungan ingin dilihat dengan cara tertentu dan sekarang menjadi lebih mudah dari sebelumnya melalui media sosial yang dapat diakses oleh banyak orang.

Manusia selalu menemukan dirinya sebagai subjek yang menarik. Selfie tidak hanya sebagai representasi diri dengan menggunakan teknologi digital tapi juga dokumentasi diri. Pelaku selfie tidak hanya berikir menampilkan diri kepada orang lain tapi berkaitan dengan emosi, benda, waktu, tempat dan sebagainya. Selfie dilakukan dengan tujuan bermacam- salah satunya sebagai pendokumentasian apa yang telah dilakukan atau dipikirkan. Kamera depan pada telepon seluler membuat fungsi kamera lebih dari sekedar mengambil gambar untuk dokumentasi. Kamera bisa digunakan untuk mengambil gambar yang mewakili emosi, benda, waktu, tempat dan sebagainya dengan lebih detail.

Trend selfie berubah yang awalnya hanya memotret diri sendiri, dengan ekspresi tertentu syaitu mulut dimanyunkan biasa disebut duck face. Efek yang diinginkan dari duck faceadalah daya tarik sensual. Selfie dengan fokus pada wajah mempunyai sifat presentasi diri. Selfie tidak hanya terlihat melalui wajah yang dibingkai pada foto tetapi bagian utama dari nilai itu terletak pada alasan keputusan untuk memotret.

Beberapa orang lebih tertarik pada selfie yang dilakukan ditempat terkenal. Tidak bisa disangkal sarana selfie terletak pada sebuah relasi yang dalam antara persepsi tubuh manusia. Tidak lagi cukup mengambil foto tempat, situasi atau objek. Kehadiran secara fisik penting walau tubuh tidak ditampilkan secara utuh.

Selfie pada awalnya dianggap perilaku narsis. Dalam pemahaman psikologi narsis atau narsistik merupakan perilaku mencintai diri sendiri dengan berlebihan. orang yang narsistik akan mengalami gangguan kepribadian, gangguan kepribadian yang dimaksud adalah gangguan kepribadian narsisistik atau narcissistic personality disorder. Gangguan kepribadian ini ditandai dengan ciri-ciri berupa perasaan superior bahwa dirinya adalah paling penting, paling mampu, paling unik, sangat eksesif untuk dikagumi dan disanjung, kurang memiliki empati, angkuh dan selalu merasa bahwa dirinya layak untuk diperlakukan berbeda dengan orang lain (www.psikologid.com).

\section{\#artselfie}

Seni menjadi seperti dunia fashion beriringan dengan hiruk pikuk dunia hiburan. Seni dan fashion selalu berjalan seiring. Kadangkadang radikal dan mengejutkan, kadangkadang tradisional dan konservatif, keduanya dinilai sesuai dengan standar subjektif dari cita rasa. Masing-masing mewakili dengan caranya sendiri suasana hati dan semangat masa. Mereka merangsang rasa dan membuat objek dari keinginan sebagai jimat dari masyarakat dan warisan budaya makmur. (Mandoki, 2007: 7-10)

Karya seni bisa dilihat melalui hubungan dengan sistem yang merepresentasi, istilah kompleks yang memungkinkan untuk memeriksa aspek penting dari praktek seni. Karya seni tidak hanya imitasi sederhana dari dunia, tapi juga berhubungan dengan penataan ulang, perombakan dan pengkodean sesuai dengan konvensi yang berbeda dari pengembangan media dan alat-alat. Cara melihat dunia, mengatur pemahaman tentang hal yang dirpresentasikan. Bisa dikatakan representasi merupakan bentuk ideologi karena didalamnya terkandung semua 
sikap yang dimiliki berkaitan dengan tanggapan terhadap karya seni, asimilasi karya seni dan proses kreatif.

Mata sebagai daya lihat adalah salah satu indera perasa pada manusia. Selama 300 tahun sesudah kamera pertama kali digunakan, banyak seniman yang memanfaatkannya untuk membantu dalam mengamati alam dan objek lain yang akan diangkat dalam karya seni.

Teknologi yang berkembang saat ini seperti kamera, komputer dan telpon mempunyai kemampuan menduplikasi atau mendokumentasi dengan mudah. Fungsi sosial seni yang berhubungan dengan nilai seni sebagai komoditas muncul saat kemudahan mereproduksi atau menduplikat terjadi. Penduplikatan menyebabkan distribusi karya semakain luas baik secara fisik atau dalam bentuk data digital. Karya seni direproduksi melalui media sosial. Aura menjadi bergeser saat pengguna media sosial menambahkann kesan pribadinya saat melihat karya seni tersebut dan memutuskan menjadi bagian dari selfie.

\section{Selfie di ArtJog (\#ArtJog)}

Pada tahun 2008 Heri Pemad Art Management menyelenggarakan pameran Jogja Art Fair dengan konsep pasar seni yang mengadaptasi art fair yang sudah rutin diselenggarkan di negara eropa dan singapura. Pasar seni yang ingin ditampilkan memang mengedepankan nilai komersil tapi dengan tampilan seperti pameran yang umum diselenggarakan sehingga karya yang dtampilkan terlihat bervariasi baik dari konsep, bentuk visual maupun teknis.

Pada penyelenggaran di tahun ketiga Jogja Art Fair (JAF) berganti nama dengan ARTJOG. Pergantian nama oleh penyelenggara dengan tujuan mengarahkan jangkauan art fair lokal ini ke wilayah yang lebih luas. Istilah JOG yang berasal dari Yogyakarta sebagai sebuah makna yang lebih pragmatis, yaitu secara kebetulan dilakukan di kota Yogyakarta. ARTJOG terbuka untuk partipasi seniman dari pelbagai kota di Indonesia

Media cetak dan elektronik berperan besar dalam menawarkan dan menaturalisasikan beraneka pilihan gaya hidup, yang setiap orang

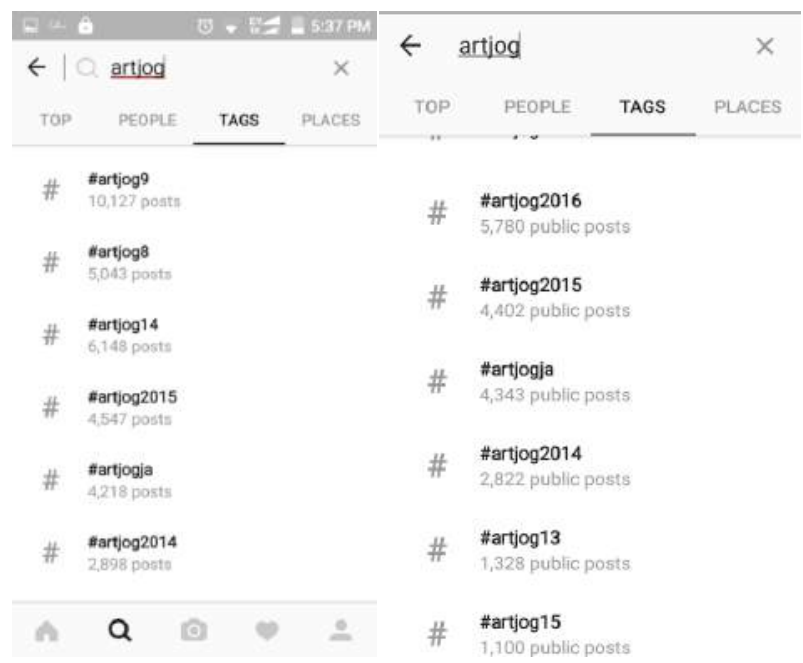

Gambar 1. Data pengunjung ArtJog pertahun berdasarkan pencarian tagar sumber: akun instagram artjog Sumber: Instagram

bebas menentukan pilihan dan seleranya. Fungsi media elektronik (khususnya televisi) lebih dari sekedar menawarkan tetapi juga membentuk gaya hidup masyarakat. (Piliang, 2006:304)

Pola media elektronik yang menawarkan gaya hidup berlanjut di media sosial. Selebriti yang pada awalnya tampil dalam waktu tertentu ditelevisi mempunyai kesempatan untuk tampil tanpa batasan ruang dan waktu melalui media sosial. Hampir semua kegiatan yangbisa di tampilkan di media sosial menjadi penunjang ketenaran selebriti. Gaya hidup yang ditampilkan juga meliputi hiburan, hobi, keluarga dan temanteman. Kegiatan mengunjungi pameranjuga menjadi tampilan yang sering dimunculkan beberapa selebriti di media sosial.

Kamera digital, ponsel pintar dan media sosial membuat orang dengan mudah membuat dan membagi representasi dirinya. Representasi diri selalu menjadi bagian dari budaya dan dilakukan oleh banyak manusia. Representasi tidak hanya melalui potret diri tapi juga buku, film, lagu dan sebagainya. Orang dengan tingkat akumulasi kekayaan tertentu atau status sosial tertentu membutuhkan media untuk representasi diri menunjukkan kelas, status dan dengan demikian membutuhkan massa penonton gaya hidup mereka. Kelas-kelas menengah baru memerlukan bahasa komunikasi baru untuk mengekspresikan gaya hidup mereka. Media sosial menjadi sarana yang sesuai dan memadai terutama dengan jangkauan yang tidak terbatas 


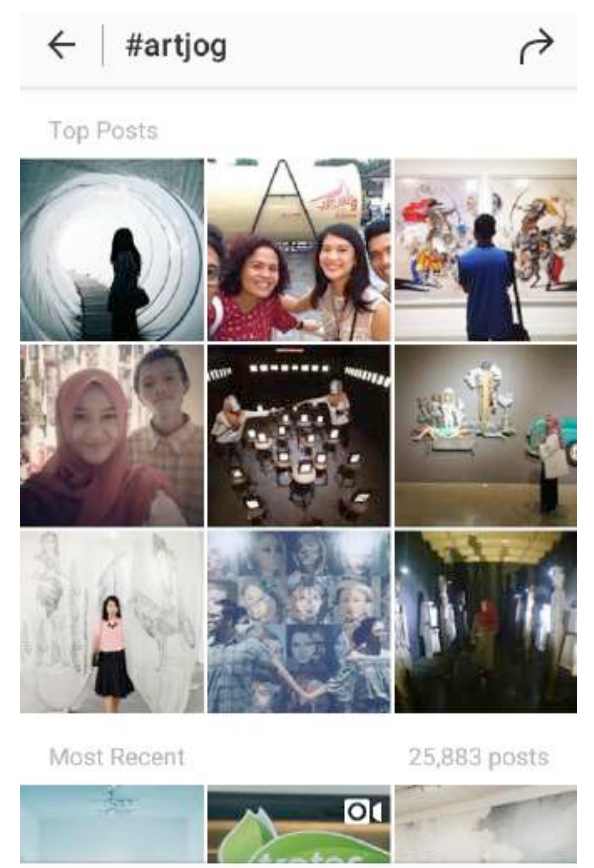

Gambar 2. Hasil Pencarian tagar Artjog Sumber: Instagram

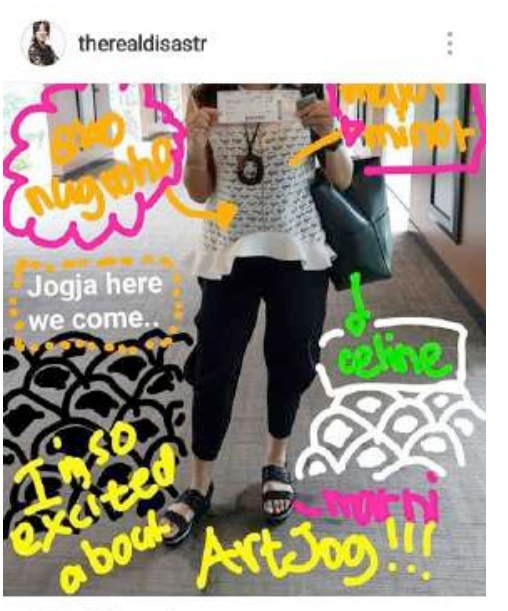

$0 \bigcirc$

- dhanitta, liyabag and 13053 others therealdisastr ArtJog2016 here we come.

Gambar 3. Serial Selfie Selebriti Dian Sastrowardoyo Sumber: Akun Instagram Dian Sastrowardoyo melalui internet.

Media sosial membuat citraan menjadi sesuatu yang dibutuhkan dan mendominasi kehidupan.Dalam dominasi citra atas realitas kehidupan sosial, eksistensi manusia di kota diredusir menjadi ontologi citraan (ontology of images). Manusia berlomba-lomba menjadi citraan (masuk televisi, tinggal di kota bercitra, menggunakan produk bercitra gaya hidup) dalam rangka menemukan eksistensinya. (Piliang, 2006:479)

Yogyakarta menjadi kota dengan citra kota pendidikan dan kota budaya. Setelah lebih dari lima kali diselenggarakan dalam kurun waktu lima tahun berturur-turut ArtJog berhasil membuat citra diri sebagai acara kesenian (Seni Rupa) yang popular di kalangan masyarakat umum tidak hanya pecinta seni.

Hastag atau tagar (tanda pagar) adalahi fitur pencari meta data online yang sering digunakan dalam penggunaan sosial media termasuk Instagram. Tagar difungsikan untuk menggolongkan tema atau topik yang lebih spesifik dalam media, di sisi lain tagar juga mempermudah orang lain untuk mencari topik yang saling berhubungan. Tagar \#ArtJog digunakan pengunggah foto yang ingin menunjukkan kehadiran mereka di media sosial.
Tagar juga memudahkan mengumpulkan data untuk melihat berapa banyak postingan ArtJog yang ada di instagram.

Penyelenggara Artjog memahami bagaimana memanfaatkan sosial media untuk memperluas informasi penyelengaraan pameran di masyarakat umum. Pemahaman ini terlihat dari adanya akun instagram resmi ArtJog. Akun tersebut tidak hanya menampilkan jadwal kegiatan, informasi dan karya yang pamerkan tapi juga foto-foto pengunjung. Pada gambar diatas terlihat tagar ArtJog ada berbagai macam. Paling umum digunakan adalah \#ArtJog, lalu \#ArtJog6 atau \#ArtJog 7 menunjukan angka banyaknya Artjog terselenggara dan \#ArtJog14 atau \#ArtJog16 menunjukan tahun ArtJog diselenggarakan. Penyelenggara mulai menggunakan instagram pada tahun 2014 dan membuka diri untuk selfie secara resmi pada tahun 2015. Penyelenggara bahkan mendorong pengunjung untuk melakukan selfie dengan karya melalui cara lomba selfie. Pengunjung diminta menggunggah selfie di pameran ArtJog dan memberikan hadiah untuk selfie terpilih sesuai dengan kriteria penyelenggara. Hal ini juga masih dilakukan pada tahun 2016.

Unggahan Instagram di akun ArtJog berupa informasi tentang lomba foto selfiedi pameran 

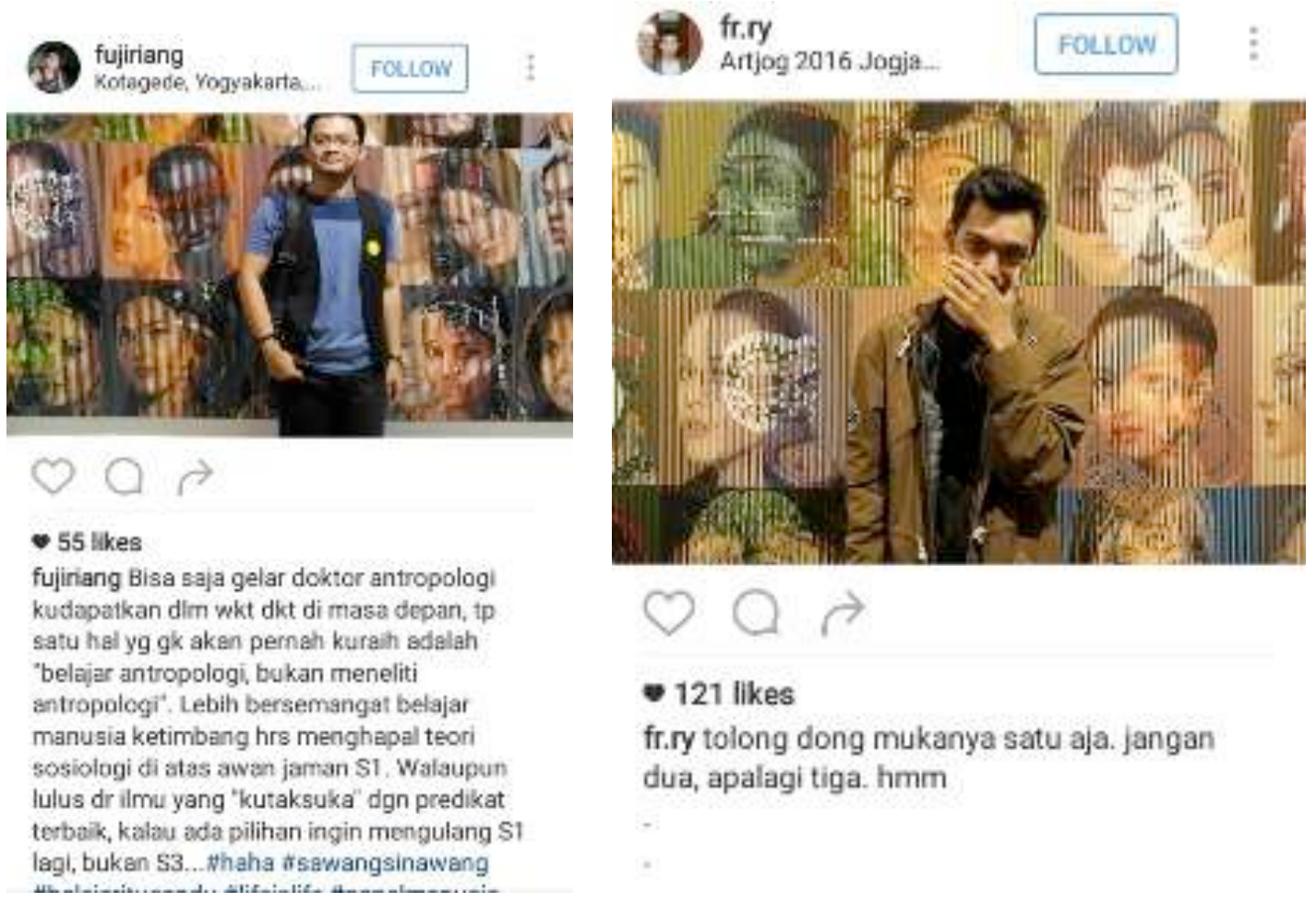

Gambar 4. Caption pada akun instagram Sumber:Instagram

tersebut. Informasi meliputi ketentuan berupa penggunaan tagar,keharusan menjadi pengikut akun Instagram ArtJog serta hadiah yang disediakan bagi pemenang.

Pada akhir bulan oktober 2016 berdasarkan pencarianmeta data menggunakan \#artjog ada unggahan foto sebanyak 25.883. Sesuai dengan penggunaan media sosial yag banyak dimanfaatkan tidak hanya untuk kepentingan pribadi semata tapi juga bisnis dalam jumlah 25.883 ada unggahan foto dengan \#artjog yang tidak menampilkan foto di pameran ArtJog. Foto-foto tersebut biasanya mendompleng tagar yang sedang populer.

Jumlah pengunjung ArtJog yang banyak berdasarkan Instagram salah satu nya adalah dengan munculnya selebritas seperti Dian Sastrowardoyo. Media sosial yang erat dengan pencitraan membuat kehadiran Dian Sastrowardoyo menjadi salah satu pemicu kuat pengunjung awam yang tidak biasa mengunjungi pameran seni rupa.

Dian Sastrowardoyo memperlihatkan kehadirannya di ArtJog secara khusus dengan serialselfie yang dilakukan. Perjalanan menuju
Yogyakarta secara khusus untuk menghadiri pembukaan pameran ArtJog diperlihatkan dengan selfie dibandara dan pesawat sambil menambahkan ketertarikannya pada karya Eko Nugroho. Setiap selfie yang dilakukan dengan karya diberi nama seniman, tidak hanya berupa taga nama senimanr tapi langsung ditulis difoto. Total ada 9 unggahan foto di instagram yang menunjukkan kehadirannya di pameran ArtJog. Dian juga mengupload pameran ArtJog di akun media sosialnya yang lain yaitu di Snap Chat. Setiap foto yang diunggah Dian Sastrowardoyo disukai lebih dari 10.000 orang

Foto yang dilihat banyak orang pada akun instagram Dian Sastrowardoyo juga menjadi salah satu pemicu banyaknya selfie di lakukan di ArtJog terutama karya yang sudah dipotretnya. Terlihat beberapa selfie dengan karya Ichwan Noor dan Eko Nugroho lebih banyak dilakukan dibanding karya lain. Tindakan tersebut ingin memperlihatkan kehadiran ditempat yang sama sengan orang yang diidolakan atau selebriti. Selfie dilakukan untuk menunjukan "saya ada disini, ditempat yang pernah didatangi idola saya" atau " saya ada ditempat yang didatangi 


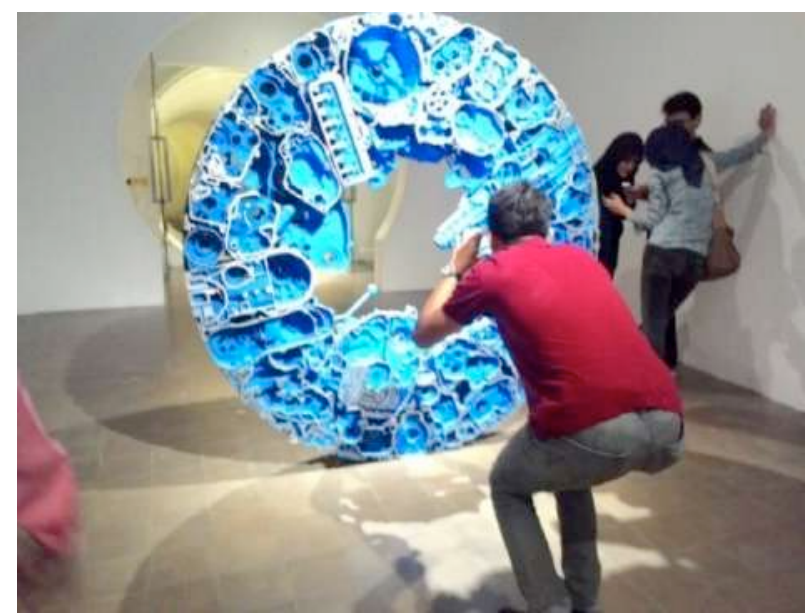

Gambar 5. Suasana Pameran saat pengunjung mengantri untuk selfie.

(Sumber Dokumentasi: Tsarah Nurhanifah)

selebriti”. Karya Ichwan Noor yang berjudul Blue Moon berukuran $180 \times 180 \times 20 \mathrm{~cm}$ disengaja atau tidak mempunyai bentuk yang menarik untuk dijadikan selfie. Karya patung ini membuat pengunjung dapat berfoto didalam karya tidak hanya di depan karya. Bagian tengah karya yang berbentuk bulat ini dibuat kosong tidak padat seperti bagian pinggir. Hal tersebut membuat karya seperti menjadi pigura saat digunakan untuk selfie. Pose selfie untuk bisa menjadikan karya seperti pigura harus jongkok.

Karya lain yang banyak digunakan sebagai selfie adalah karya Eko Nugroho. Berbeda dengan karya Ichwan Noor yang interaktif terutama untuk selfie dengan bentuk 3 dimensional karya Eko Nugroho dengan judul Street Talk Series yang menggunakan media bordir dengan ukuran 96-150 x 150 × $96 \mathrm{~cm}$ merupakan karya 2 dimensional yang didisplay degan cara ditempel di tembok. Area karya yang luas membuat karya ini diletakkan dalam satu ruangan sendiri. Posisi karya membuat pose selfie cukup dengan berdiri.

Instagram memang media sosial yang mengutamakan foto sebagai ajang interaksi tapi judul (caption) foto saat diunggah juga menjadi ajang pengukuhan selfie. Judul tidak berfungsi menerangkan foto yang diunggah. Judul sering dibuat sesuai keinginan dan kebutuhan pengguna selfie. Seperti pada gambar selfie dengan karya Theressia ada judul yang dengan pertanyaan "Selambu atau Gorden?" atau "Kapan kita vakansi lagi?”
Beberapa selfie bahkan membuat judul puitis atau bahkan seperti ungkapan isi hati yang kadang dikaitkan dengan karya atau tidak terkait sama sekali. Pada selfie yang dilakukan akun Naritanif dengan karya FX Harsono yang berjudul Undisclosed Identity saat diunggah judul yang dibuat adalah " Berjalan dalam kegelapan bersama seorang teman itu lebih baik daripada berjalan sendirian dalam cahaya terang benderang, btw gangerti kenapa posenya gitu ewh". Judul seperti curahan hati saat diunggah terlihat pada selfie yang dilakukan akun Fujiriang dengan karya Galam Zulkifli yang berjudul The Beauty of RelativityII.

Biasanya satu orang tidak hanya melakukan selfie pada satu karya tapi juga banyak karya. Selfiedengan banyak karya tidak langsung diunggah saat itu juga tapi lain waktu. Ini menjadi seperti stok foto untuk pengguna Instagram yang memang konsisten membangun pencitraan diri di Instagram melalui selfie. Biasanya foto yang seperti tersebut diunggah dengan diberi tagar \#latepost.

Terlihat pada gambar akun instagram Zietha_V dengan selfie lebih dari satu. Selfie seperti ini biasanya dilakukan oleh orang yang membangunpencitraan melaluifashion. Initerlihat dari pakaian dan aksesoris yang digunakan. Pose yang dipilih juga memperkuat fokus utama pada pengguna selfie dan memperlihatkan karya seni sebagai latar belakang selfie. Biasanya selfie seperti ini menggunakan kamera DSLR walaupun nanti saat diunggah tetap menggunakan ponsel pintar berbasis android.

Beberapa selfie merespon karya dengan merepresentasikan karya melalui pose selfie dan judul. Salah satunya yang dilakukan oleh akun D.N.A 13 dengan nama asli Shinto Dandiwa. Melalui wawancara dengan memanfaatkan fitur pesan langsung di Instagram Shinto menjelaskan baru pertamakali datang ke pameran ArtJog pada tahun ini, 2016. Selama di area pameran banyak melakukan selfie dengan berbagai gaya sampai dingatkan oleh penjaga pameran. Tidak ada alasan khusus saat melakukan selfie, cuma sepintas saja punya ide mau foto dengan gaya seperti pada gambar dengan objek seni dibelakangnya. Objek seni disatukan dengan ekspresi diri, dituang dalam bentuk foto dan diperkuat dengan judul. 
Pemilihan karya lebih kepada bentuk karya bukan seniman.

Pengunjung yang mencantumkan nama seniman pada tagar biasanya memang sering mendatangi pameran salah satunya akun Erwitami. Dalam wawancara melalui pesan langsung di Instagram Erwitami mengatakan sudah mendatangi pameran ArtJog sejak tahun 2012 dan juga mengunjungi pameran lain seperti Biennale Jogja. Pada pameran yang didatangi jika ada karya yang menarik memang difoto walau tidak semuanya dengan melakukan selfie. Pemilihan karya lebih kepada bentuk visual karya yang dianggap menarik bukan berdasarkan seniman. Erwitami yang memang sering mendatangi pameran sudah memahami bahwa setiap karya yang ada dibuat oleh seniman yang berbeda sehingga mencantumkan nama seniman.

Selfie juga dilakukan dalam bentuk merespon karya dengan persepsi masing-masing. Selfie yang dilakukan oleh akun Astronotkurus dengan karya Rudi Mantofani dengan judul Dunia dan Bumi. Pada karya itu dia melihat karya sebagai Apel yang ada gambar peta dunianya jadi dia berpiki saat berpose seperti itu, ia seakan ingin dunia mendengar opininya. Pada judul selfie ditulis " saya sedang memeragakan adegan pidato disuatu tempat..”. Berdasarkan dari beberapa wawancara mereka menganggap tujuan utama pergi ke ArtJog adalah untuk melakukan selfie. Seperti yang dikatakan oleh akun Ulfaochida "sekarang lagi jamannya foto-foto yang backgroundnya keren gitu kan...nah saya cari view biar hasil fotonya lumayan bagus hehe saya bukan pecinta seni rupa mb, saya cuma suka aja”.

Jika melihat data berdasarkan \#ArtJog2016 ada sekitar 5700 unggahan foto di Instagram. Seperti yang sudah dijelaskan oleh beberapa pengunjung yang melakukan selfie, mereka berfoto dilebih dari satu karya dan tidak semuanya dipublikasikan. Setiap foto selfie yang dilakukan terkadang membutuhkan lebih dari satu kali pengambilan atau jepretan serta persiapan untuk berpose. Situasi tersebut membuat ada sekitar hampir lima menit waktu yang dibutuhkan oleh pelaku selfie.

Waktu yang dibutuhkan terkadang lebih banyak hingga membuat kerumunan didepan karya yang sering digunakan untuk selfie seperti karya Ichwan Noor. Terlihat ada beberapa persiapan yang dilakukan pengunjung untuk melakukan selfie. Persiapan dimulai dari alat perekam, tidak selalu hanya ponsel pintar yang digunakan untuk memotret. Terlihat beberapa pengunjung memang menyiapkan diri dengan membawa kamera DSLR, tongkat selfie atau lensa tambahan untuk ponsel. Selain itu terlihat cara dan gaya berpakaian juga dipersiapkan. Sebagian besar selfie tidak dilakukan sendiri, minimal dua orang biasanya berkelompok lebih dari dua orang.

Penyelenggara ArtJog memahami dampak positif dan negatif darimaraknya selfie yang dilakukan selama pameran. Untuk mengurangi resiko seperti karya tersenggol yang bisa mengakibatkan kerusakan beberapa hal dilakukan salah satunya menawarkan pengunjung untuk menitip barang bawaan seperti tas agar tidak menyenggol karya. Penjaga pameran juga dipersiapkan dengan jumlah yang memadai dan aktif mengingatkan pelaku selfie untuk tidak menyentuh karya kecuali karya yang memang interaktif atau jika peaku selfie terlalu dekat dengan karya.

Ramainya pengunjung awam juga dipahami oleh penyelenggara ArtJog. Sejak 2 tahun lalu diadakan tur kuratorial yang terbuka untuk umum dengan waktu tertentu. Tur kuratorial dipandu langsung oleh kurator pameran Bambang Witjaksono dilakukan beberapakali selama pameran berlangsung. Tahun ini wilayah edukasi pengunjung diperluas dengan menambah sesi acara yang bertujuan mempertemukan seniman dan pengunjung yang diberi nama "Meet The Artist". Acara tersebut bertujuan mengedukasi pengunjung tentang karya seni dan proses berkesenian yang dilakukan seniman. Pada tahun 2017 penyelenggara ArtJog yaitu Heri Pemad Management berniat lebih aktif dengan memberikan bekal informasi kuratorial pameran yang lebih detail ke penjaga pameran agar bisa setiap saat memberikan info karya dengan detail kepada pengunjung.

\section{Kesimpulan}

Apresiasi yang diharapkan oleh seniman meliputi kesadaran mengamati karya seni dengan 
lebih intens untuk menemukan dan melihat pencapaian proses kreatif yang telah dilakukan seniman.Untuk menghasilkan apresiasi seperti itu dibutuhkan wawasan yang memadai. Apresiasi sebagai bentuk penghargaan terhadap karya seni membutuhkan wawasan meliputi teknis, media, jenis, karya serta semua elemen visual pada karya. Semua wawasan tersebut membutuhkan edukasi baik secara formal ataupun informal. Secara informal wawasan mengenai karya seni bisa didapat melalui internet. Pengalaman visual yang bervariasi dan kuat melalui internet dianggap sudah bisa menjadi dasar yang agak memadai bagi pengunjung awam dalam melihat karya seni. Agak memadai ini berhubungan dengan kesadaran memilih bentuk visual yang menarik terutama terlihat dari selfie yang dilakukan.

Terlihat dari selfie yang dilakukan pada pameran ArtJog karya dipilih karena dianggap menarik untuk difoto secara khusus menjadi bagian dari selfie. Dari 25.883 unggahan di Instagram yang menggunakan \#artjog didominasi oleh foto selfie. Foto karya tanpa berupa selfie sangat jarang. Pemahaman bahwa karya seni adalah hasil kreatifitas yang patut dihargai lebih dari sekedar latar belakang selfie bisa dimulai dengan mengarahkan pelaku selfie untuk juga membaca keterangan pada setiap karya yang dipilih. Dari membaca keterangan karya mereka bisa menambah wawasan dengan melihat bahwasetiap karya adalah hasil karya seniman mempunyai judul dan media yang berbeda.

Pameran ArtJog adalah pameran karya dari banyak seniman. Masyarakat awam memahami karya-karya tersebut adalah ArtJog. Masyarakat awam banyak yang belum memahami bahwa ArtJog merupakan pameran kolektif dari banyak seniman.Media sosial membuka peluang sebagai sarana edukasi dan pengenalan karya seni. Aktivitas selfie yang memicu banyak masyarakat awam mendatangi pameran seni rupa bisa dilihat sebagai peluang untuk meningkatkan kualitas dan intensitas apresiasi seni di masyarakat umum.

\section{Daftar Pustaka}

Benjamin, W. (2008). The Work of Art in the Age of Its Technological Reproducibility, and Other Writings on Medi. USA: Harvard College.

Blossom, J. (2009). Content Nation: Surviving and Thriving as Social Media Changes Our Work, Our Lives, and Our Future. USA: Wiley Publishing.

Lois, F.-R. (2013). Understanding Art. Boston: Wadsworth.

Mandoki, K. (2007). Everyday Aesthetics. USA: Ashgate Publishing Limited.

Morris, D. (1977). Man Watching: A Field Guide To Human Behaviour. New York: Harry N. Abrams, Inc.

Piliang, Y. A. (2006). Dunia Yang Dilipat: Tamasya melampaui Batas-batas Kebudayaan. Yogyakarta: Jalasutra.

Steven, M., \& Cahn, E. (2004). The Blackwell Guide to Aesthetics. USA : Blackwell Publishing. USA: Blackwell Publishing. www. oxforddictionaries. (n.d.) 